\title{
Capital investment, internationalization, and firm performance: An empirical study of listed manufacturing firms in the Indonesian stock exchange in 2014-2019
}

\author{
Yovita \& D. Marciano \\ University of Surabaya, Surabaya, Indonesia
}

\begin{abstract}
This study aims to answer whether capital investment of a firm affects the firm's degree of internationalization and to test the effect of internationalization on the firm performance. This research focuses solely on 72 Indonesian manufacturing firms that have been actively engaging in export activities from 2014 to 2019, making up a total of 360 observation points. Capital investment is measured using CAPEXTA, while internationalization is measured using FSTS and the internationalization level change is measured using FSG. In addition, to measure the effect of internationalization on the firm performance, this study uses ROA and Tobin's Q. The control variables include industry return, firm size, leverage, tangible asset ratio, market-to-book ratio, gross profit margin, and sales growth. The hypotheses are confirmed using simple linear regression and ordinary least-squares. The results show that CAPEXTA and internationalization (FSTS) have a significantly negative relationship, and there is an evidence of non-linear relationship. The impact of CAPEXTA on FSG is also shown to be significantly negative and non-linear. While FSTS and ROA have a positive U-shaped relationship, and FSTS shows that it has a directly positive relationship to Tobin's Q.
\end{abstract}

\section{INTRODUCTION}

Internationalization is a complex process led by the globalization effect all over the countries. Firms will surely adapt to the globalization through their operational process. One of the processes could be expanding to the international markets, doing foreign direct flow through investing to the host country, and many more. Riahi-Belkaoui (1994) had done a research regarding the effect of internationalization to firms in the United States of America. The result shows that internationalization did have a significant effect, which could be seen from the aspects of sales, profit, and their assets in foreign countries. It is said that the effect of internationalization was ranging from $10 \%$ to over $90 \%$ of the firm's total operations. Seeing how the internationalization has much impact in the USA, does it also have the same effect in the developing countries, especially Indonesia? Indonesia has been showing great growth in terms of GDP per year compared to other countries, and it is expected to be one of the leading big economy countries in 2024 (IMF and World Bank).

Internationalization simply becomes unavoidable, as some researchers consider internationalization as a firm's strategy. Strategy can be divided into two: (1) growth strategy (Capar \& Kotabe; Kylaheiko et al. in Vithessonthi, 2017) and (2) diversification strategy (Gulamhussen et al. in Vithessonthi, 2017). These two strategies positively support the firm performance to generate more income and operate efficiently. In addition, some firms choose to expand by planting their firms abroad as one of their strategies to mitigate the investment risk of having big capital investment (Vithessonthi, 2017). This raises the question of whether internationalization does work as a strategy and improve the firm performance.

Meanwhile, the relationship of capital investment and internationalization also piqued the interest of researchers. One of the driving factors for the degree of internationalization by the firm is 
their capital investment. Firms with higher capital investment would find expanding abroad benefiting to them. Aside from their strategy to mitigate the investment risk, Vithessonthi (2017) said that firms with large capital investment which intend to capitalize the resources and capabilities in order to gain competitive advantage should expand abroad and enter foreign markets. This summarizes how internationalization depends on the firm's long-term assets and capital investments. Further investigation regarding the relationship of capital investment and internationalization will be discussed in this study. The proposed measurement to accurately depict internationalization that will be used is foreign sales to total sales (FSTS). FSTS has been widely used in previous studies regarding internationalization. Nevertheless, this study also includes foreign sales growth (FSG) to identify if foreign sales is a capital investment's function. FSG is used to know if there is even a slight change in the internationalization level.

Further discussion about the relationship between internationalization and firm performance shows diverse results. Sun et al. (2018) and Hsu et al. (2013) found a significantly positive relationship of internationalization and firm performance, while other studies from Singla and George (2013) and Salim et al. (2018) show a negative relationship. This study will also add another variable to measure the firm performance, aside from ROA, which is widely used in other previous studies, that is, Tobin's Q. Tobin's Q is used to represent firm performance in the long run and could also be defined as the firm value in other studies. Based on the aforementioned reasons, there are two hypotheses that will be tested: (H1) capital investment positively impacts internationalization and $(\mathrm{H} 2)$ internationalization positively impacts firm performance.

\section{DATA}

The data consist of publicly listed manufacturing firms in Indonesian Stock Exchange from 2014 to 2019. The firms need to be actively engaging in export activities. For this study, the data of 72 public manufacturing firms are collected from their audited financial statement each year. In total, there are 360 observation points to be analyzed in this study. The dependent variables used are FSTS and FSG for internationalization, and both ROA and Tobin's Q as proxy for firm performance. We use FSTS and FSG to test the capital investment to internationalization model. FSTS is measured as firm's foreign sales to firm's total sales, while FSG is measured as the first difference in the natural logarithm of firm's foreign sales. In the internationalization (FSTS) to firm performance model, we use ROA and Tobin's Q. ROA is measured as the ratio of EBIT to total assets. Tobin's Q is computed as the ratio of the sum of the market capitalization and firm's total debt to firm's total asset.

The independent variable used in the capital investment and internationalization model is CAPEXTA, as a proxy to capital investment. CAPEXTA is measured as the ratio of capital expenditure to total asset of a firm. The independent variable used in internationalization and firm performance model is FSTS, as a proxy to internationalization. FSTS is measured as the ratio of foreign sales to total sales, as stated in the previous section. The macroeconomics variable that we use to control the internationalization is the GDP growth rate (GDPGROWTH). Aside from the macroeconomic control variable, this study also applies several firm-specific control variables. These control variables include (1) firm Size (FSIZE), measured as the natural logarithm of total assets, (2) leverage (LEV), measured as the ratio of total debt to total asset, (3) tangible asset ratio (PPETA), defined as the ratio of property, plant, and equipment of a firm to total assets, (4) market-to-book value (MBV), measured as the ratio of market capitalization to book value of total equity, (5) gross profit margin (GPM), calculated by dividing gross profit to total sales, (6) and sales growth (SALESGROWTH), which is computed as the first difference of the natural logarithm of total sales.

We first analyze the impact of capital investment to internationalization into two models; the first model is to detect a linear effect, while the second model is to detect if there is a nonlinear effect. The first part is to use FSTS as a proxy of internationalization. In addition to that, $\varepsilon$ is an error term, and $i$ and $t$ stand for firm and time, respectively. The independent variable and control variables are set to one-period lag. 


$$
\begin{aligned}
\text { FSTS }_{i, t}= & \alpha+\beta_{1} \text { CAPEXTA }_{i, t-1}+\beta_{2} \text { GDPGROWTH }_{i, t-1}+\beta_{3} \text { FSIZE }_{i, t-1}+\beta_{4} L E V_{i, t-1} \\
& +\beta_{5} \text { PPETA }_{i,-1}+\beta_{6} \text { MBV }_{i, t-1}+\beta_{7} \text { GPM }_{i, t-1}+\beta_{8} \text { SALESGROWTH }_{i, t-1} \\
& +\beta_{9} \text { ROA }_{i,-1}+\varepsilon_{i, t} \\
\text { FSTS }_{i, t}= & \alpha+\beta_{1} \text { CAPEXTA }_{i, t-1}+\beta_{2} \text { CAPEXTA }_{i, t-1}^{2}+\beta_{3}{\text { GDPGROWTH }+\beta_{4} \text { FSIZE }_{i, t-1}} \\
& +\beta_{5} \text { LEV }_{i,-1}+\beta_{6} \text { PPETA }_{i, t-1}+\beta_{7} \text { MBV }_{i, t-1}+\beta_{8} \text { GPM }_{i, t-1} \\
& +\beta_{9} \text { SALESGROWTH }_{i,-1}+\beta_{10} \text { ROA }_{i,-1}+\varepsilon_{i, t}
\end{aligned}
$$

The second part is to use the foreign sales growth (FSG) rate as a proxy to internationalization. The idea of using FSG is to address the slight change that goes undetected in FSTS, which could be the result of the capital investment effect.

$$
\begin{aligned}
\text {FSG }_{i, t}= & \alpha+\beta_{1} \text { CAPEXTA }_{i, t-1}+\beta_{2} \text { GDPGROWTH }_{i, t-1}+\beta_{3} \text { FSIZE }_{i, t-1}+\beta_{4} \text { LEV }_{i, t-1} \\
& +\beta_{5} \text { PPETA }_{i,-1}+\beta_{6} M B V_{i, t-1}+\beta_{7} \text { GPM }_{i, t-1}+\beta_{8} \text { SALESGROWTH }_{i, t-1} \\
& +\beta_{9} \text { ROA }_{i, t-1}+\varepsilon_{i, t} \\
\text { FSG }_{i, t}= & \alpha+\beta_{1} \text { CAPEXTA }_{i, t-1}+\beta_{2} \text { CAPEXTA }_{2 i, t-1}+\beta_{3} \text { SDPGROWTH }_{i, t-1}+\beta_{4} \text { FSIZE }_{i, t-1} \\
& +\beta_{5} \text { LEV }_{i,-1}+\beta_{6} \text { PPETA }_{i, t-1}+\beta_{7} M B V_{i, t-1}+\beta_{8} \text { GPM }_{i, t-1} \\
& +\beta_{9} \text { SALESGROWTH }_{i,-1}+\beta_{10} \text { ROA }_{i, t-1}+\varepsilon_{i, t}
\end{aligned}
$$

The impact of internationalization on firm performance is analyzed through two parts, as we replace the proxy of firm performance as ROA and Tobin's Q (TBQ) in each model.

$$
\begin{aligned}
\text {ROA }_{i, t}= & \alpha+\beta_{1} \text { FSTS }_{i, t-1}+\beta_{2} \text { GDPGROWTH }_{i, t-1}+\beta_{3} \text { FSIZE }_{i, t-1}+\beta_{4} \text { LEV }_{i, t-1}+\beta_{5} \text { PPETA }_{i, t-1} \\
& +\beta_{6} \text { MBV }_{i,-1}+\beta_{7} \text { GPM }_{i, t-1}+\beta_{8} \text { SALESGROWTH }_{i, t-1}+\beta_{9} \text { ROA }_{i, t-1}+\varepsilon_{i, t} \\
\text { ROA }_{i, t}= & \alpha+\beta_{1} \text { FSTS }+\beta_{2} \text { FSTS }_{i 2, t-1}+\beta_{3} \text { GDPGROWTH }_{i, t-1}+\beta_{4} \text { FSIZE }_{i, t-1}+\beta_{5} \text { LEV }_{i, t-1} \\
& +\beta_{6} \text { PPETA }_{i,-1}+\beta_{7} \text { MBV } \\
& +\beta_{10, t-1}+\beta_{8} \text { RPA }_{i, t-1}+\varepsilon_{i, t}
\end{aligned}
$$

Then, we analyze the impact of internationalization on Tobin's Q (TBQ) as a proxy to firm performance. All the other variables have the same definition, as has already been stated.

$$
\begin{aligned}
& T B Q_{i, t}=\alpha+\beta_{1} \text { FSTS }_{i, t-1}+\beta_{2} \text { GDPGROWTH }+\beta_{3} \text { FSIZE }_{i, t-1}+\beta_{4} L E V_{i, t-1}+\beta_{5} \text { PPETA }_{i, t-1} \\
& +\beta_{6} M B V_{i,-1}+\beta_{7} \text { GPM }_{i, t-1}+\beta_{8} \text { SALESGROWTH }_{i, t-1}+\beta_{9} R_{\text {ROA }} A_{i, t-1}+\varepsilon_{i, t} \\
& T B Q_{i, t}=\alpha+\beta_{1} F S T S+\beta_{2} \text { FSTS }_{i 2, t-1}+\beta_{3} \text { GDPGROWTH }_{i, t-1}+\beta_{4} \text { FSIZE }_{i, t-1}+\beta_{5} L E V_{i, t-1} \\
& +\beta_{6} \text { PPETA }_{i,-1}+\beta_{7} M B V_{i, t-1}+\beta_{8} \text { GPM }_{i, t-1}+\beta_{9} \text { SALESGROWTH }_{i, t-1} \\
& +\beta_{10} R O A_{i, t-1}+\varepsilon_{i, t}
\end{aligned}
$$

\section{RESULTS AND DISCUSSION: CAPITAL INVESTMENT TO INTERNATIONALIZATION (FSTS)}

The data processed provide some evidence that there is indeed a relationship of capital investment to internationalization, but it differs from the hypotheses. This suggests that every increase on capital investment would lessen the degree of internationalization. However, the data indicate that there is a non-linear relationship of capital investment to internationalization. The result is in line with the previous research by Salim et al. (2017). The U-shaped relationship confirms that mostly Indonesian 
public firms still target their domestic market, as they already have competitive advantages in their home country. Moreover, the negative relationship could be a result of the one-period timelagged variables in the regression. The assumption made is that the capital investment budget would not be immediately used and brings out a positive return in the same year (Vithessonthi, 2016). Internationalization is defined solely by companies' capability of generating foreign sales. Vithessonthi (2017) also argued that the result of negative or non-existent relationship of capital investment on internationalization could be due to how firms are risk-averse. If the firm policy is driven by their risk-averse profile to the internationalization process, then they would hesitate and could not expand the business more into the international market. The U-shaped relationship also implies that the negative effect will be decreased with more increase in the more capital investment; it is conditional related to the size of capital investment (Vithessonthi, 2017).

\subsection{Capital investment to FSG}

It is apparent that there is an impact of capital investment on FSG as a proxy to internationalization. The effect is negative, and there is also an evidence of the non-relationship evidence. Vithessonthi (2016) argued that the coefficient of CAPEXTA should be positive if firms with larger capital investment are to focus on their international business through export. Instead, the following regression results show otherwise. This adds more to the argument that Indonesian public firms are still indeed focusing on their domestic market, as the domestic market alone has so much potential, with Indonesia being one of the largest consumer countries; $74 \%$ of the total sales goes to the home country alone. The result could be driven with the downtrend of the Indonesia's export. The result also confirms that FSG is not a function of capital investment. Vithessonthi (2016) in his research also found the evidence of a significantly negative relationship of CAPEXTA to FSG with the moderating variables of firm size.

\subsection{Internationalization (FSTS) to firm performance (ROA)}

The data regressed show no linear relationship detected in model 5. Meanwhile, when the FSTS is computed to square FSTS in model 6, we found an evidence of a non-linear relationship, that is, a positive U-shaped relationship. The U-shaped relationship explains how it is related to the early internationalization. In the early stage of internationalization, firms tend to have low firm performance as to how they are still adapting and get to know about the international market, as they collect foreign resources and new knowledge to be applied within. The firm still faces uncertainty toward the new foreign market. However, once they become familiar with the international markets and know how the target market works, they will start thriving and become positive (Contractor et al., 2007; Capar and Kotabe, 2003; Ruigrok and Wagner, 2003 in Altaf and Shah, 2016). Previous studies show that the benefit of doing internationalization will be experienced once the firm successfully adjusts to the foreign markets. Coombs et al. (2009) in Altaf and Shah (2016) identified one of the benefits mentioned as risk diversification. As stated before, one of the driving factors for firms to do internationalization is risk mitigation. According to the data, there is a negative linear relationship in model 6, alongside the positive U-shaped relationship. It only emphasizes the evidence that the internationalization and firm performance relationship is conditional, related to the stage of internationalization. Because the variables are one-period time-lagged, we can conclude that the time needed for internationalization to benefit the firm could be more than one year.

\subsection{Internationalization (FSTS) to firm performance (Tobin's Q)}

Regressed data indicate that there is a positive direct relationship of internationalization to Tobin's $\mathrm{Q}$ as firm performance. A non-linear relationship is not found. The result is in line with those reported by Sun et al. (2018), Riahi-Belakaoui (1999), and Olsen and Elango (2016), who stated that internationalization positively affects the firm performance/firm value. Olsen and Elango (2016) argued that the geography of the sample gathered played an important role. In Indonesia, 
the firms are located at smaller home markets (considering the U.S. market and international markets), which drives them to do internationalization. This leads to the increase in Tobin's Q as firm performance (or firm value). Investors consider the degree of internationalization as one of the important factors; so they are willing to invest in these firms, and the market capitalization of the firm will grow.

\section{CONCLUSION AND IMPLICATION}

It can be concluded that capital investment negatively impacts the internationalization level, while there is also an evidence of a U-shaped relationship. On the other hand, the study confirms that internationalization affects firm performance (ROA) in a non-linear model, that is, a U-shaped relationship. However, there is a positive relationship on the impact of internationalization to Tobin's Q as firm performance.

\section{REFERENCES}

Altaf, N. and Farooq Ahmad Shah (2015), "Internationalization and firm performance of Indian firms: Does product diversity matter?", Pacific Science Review B: Humanities and Social Sciences, Vol. 1, p. 76-84.

Ater, Daniel Kon (2017), "The Joint Effect of Firm Growth, Macroeconomic Factors and Capital Structure on The Value of Nonfinancial Firms Listed On The Nairobi Securities Exchange", International Journal of Economics, Commerce, and Management, Vol. 5, Issue 9, p. 618-628.

Billett, M.T. et al. (2011), "The influence of governance on investment: Evidence from a hazard model", Journal of Financial Economics, Volume 102, Issue 3, Pages 643-670.

Chung, Chris Changwha, et al. (2013), "Internationalization and Performance of Firms in China:

Moderating Effects of Governance Structure and the Degree of Centralized Control", Journal of International Management, Vol. 19, Issue 2, Pages 118-137.

Duchin, R. et al. (2010), "Costly external finance, corporate investment, and the subprime mortgage credit crisis", Journal of Financial Economics, Volume 97, Issue 3, Pages 418435.

Khamees, B.A., Al-Fayoumi, N. and Al-Thuneibat, A.A. (2010), "Capital budgeting practices in the Jordanian industrial corporations", International Journal of Commerce and Management, Vol. 20 No. 1, pp. 49-63.

Khasawneh, A.Y. and Dasouqi, Q.A. (2017), "Sales nationality and debt financing impact on firm's performance and risk: Evidence from Jordanian companies", EuroMed Journal of Business, Vol. 12 No. 1, pp. $103-126$.

Luo, Xueming and Zheng, Qinqin (2018), "How firm internationalization is recognized by outsiders: The response of financial analysts", Journal of Business Research, Volume 90, Pages 87-106.

Likitwongkajon, N. and Vithessonthi, C. (2020), "Do foreign investments increase firm value and firm performance? Evidence from Japan", Research in International Business and Finance, Vol. 51.

Olsen, B. and Elango, B. (2005), "Do Multinational Operations Influence Firm Value? Evidence form the Triad Regions", International Journal of Business and Economics, Vol. 4, No. 1, p. 11-29.

Rely, Gilbert and Regina Jansen Arsjah (2018), "An Effecting Ownership Structure in Firm Value Towards Offshore Debt Financing in Manufacturing Firms", Research Journal of Finance and Accounting, Vol. 9, No. 12 , p. $46-56$.

Riahi-Belkaoui, Ahmed (1999), "The degree of internationalization and the value of the firm: theory and evidence", Journal of International Accounting, Auditing, and Taxation, Vol. 8, Issue 1, Pages 189-196.

Salim et al. (2017), "Capital Investment, Internationalisation, and Firm Performance: An Empirical Study of Listed Manufacturing Firms in The Indonesian Stock Exhange 20112015", Proceeding The International Conference: The Roles of Social Science and Humanities in Socio-Economic Development and International Integration.

Tan, Yong and Christos Floros (2012), "Bank profitability and GDP growth in China: A Note", Journal of Chinese Economics and Business Studies, Vol. 10, Issue 3, pp. 267-273.

Vithessonthi, C. and Olimpia C. Racela (2016), "Short- and long-run effects of internationalization and R\&D intensity on firm performance", Journal of Multinational Financial Management, Vol. 34, p. 28-45. Vithessonthi, Chaiporn (2016), "Capital investment, internationalization, and firm performance: Evidence from Southeast Asian countries", Research in International Business and Finance, Vol. 38, pp. 393-403.

Vithessonthi, Chaiporn (2017), "Capital investment and internationalization", Journal of Economics and Business, Volume 90, Pages 31-48. 